\title{
Analisis Motivasi Pengunjung Museum Macan Jakarta
}

\author{
Rina Fitriana ${ }^{1 *}$, Nurima Rahmitasari ${ }^{2,3}$, Marcelina Yoseli ${ }^{3}$ \\ ${ }^{1}$ Politeknik Sahid \\ ${ }^{2}$ Guangzhou University \\ ${ }^{3}$ Sekolah Tinggi Pariwisata Trisakti \\ *rinafitriana@polteksahid.ac.id
}

\begin{abstract}
MACAN Museum (Museum of Modern and Contemporary Art in Nusantara) has a wide collection of modern and contemporary Indonesian arts up to the first international scale in Indonesia, and is one of the cultural tourism objects in Jakarta. The collection is packaged with the concept of art shows and exhibitions that can be enjoyed by every visitor. This research aims to analyze the motivation of visitors coming to the museum using quantitative descriptive methods. Unit of analysis in this research is the visitors of MACAN museum, meanwhile the independent variable is the visitors' motivation. Data was taken by giving questionnaire to 100 respondents, by having observation, and by doing structured interview. The questionnaire then analyzed by using excel. The results show that of the four motivations on visiting the museum, cultural motivation obtained the highest value as the most motivating factor for visitors with a value of 4.19, and the average total value of the four motivations is 3.84 which states that visitors are motivated to visit the MACAN museum.
\end{abstract}

Keywords: Museum; Visitors Motivation; Contemporary Arts; MICE

\begin{abstract}
ABSTRAK
Museum Macan Museum MACAN (Museum Modern and Contemporary Art in Nusantara) merupakan museum yang memiliki koleksi seni modern dan kontemporer Indonesia pertama yang berskala internasional dan merupakan salah satu objek wisata budaya. Koleksi museum ini dikemas dalam bentuk pertunjukan seni dan pameran yang dapat dinikmati setiap pengunjung. Penelitian ini bermaksud mengungkap motivasi pengunjung yang datang ke Museum Macan dengan menggunakan metode peneltian deskriptif kuantitatif. Unit analisis dalam penelitian ini adalah pengunjung museum MACAN dan variabel penelitian yaitu motivasi berkunjung. Pengumpulan data dilakukan teknik kuisioner yang disebar pada 100 responden, observasi, dan wawancara terstruktur yang kemudian dianalisis menggunakan excel. Hasil penelitian menunjukan bahwa dari keempat motivasi yang ada, motivasi budaya memperoleh nilai tertinggi sebagai faktor yang paling memotivasi kedatangan pengunjung dengan nilai 4,19. Dan dari keempat motivasi nilai total rata-rata keempat motivasi tersebut adalah 3,84 yang menyatakan bahwa pengunjung termotivasi untuk mengunjungi museum MACAN.
\end{abstract}

Kata Kunci: Museum; Motivasi Pengunjung; Seni Kontemporer; MICE 


\section{PENDAHULUAN}

Pariwisata di Indonesia merupakan salah satu sektor yang memiliki pengaruh cukup besar dan memiliki peranan penting dalam perekonomian Indonesia. Pada tahun 2016, pariwisata menempati urutan kedua dalam pengkontribusian penerimaan devisa terbesar bagi Indonesia setelah industri minyak kelapa sawit. (Sumber: finance.detik.com).

Dewasa ini, pariwisata bukan hanya berkaitan dengan hiburan dan rekreasi saja, akan tetapi dapat dipadukan dengan kegiatan bisnis. Hal tersebut sudah sangat dikenal dikalangan masyarakat dengan istilah MICE yang merupakan akronim dari bahasa inggris yaitu, Meeting, Incentive, Convention, and Exhibition (Pertemuan, Insentif, Konvensi, dan Pameran). Menteri Pariwisata periode 2014 - 2018, Arief Yahya dalam surat kabar online (website sporttourism.id) menyatakan bahwa MICE berpotensi menjadi tumpuan pariwisata Indonesia kedepannya. Sebagai negara yang memiliki beragam destinasi wisata, banyak kota di Indonesia yang berpotensi kuat jadi lokasi MICE tingkat internasional. Pada awal 2017, Kementerian Pariwisata Indonesia telah menetapkan dan mempublikasi 16 kota yang siap jual (Jakarta, Bali, Bandung, Surabaya, Solo, Yogyakarta, Makassar, Batam, Medan, Manado, Padang, Palembang, Balikpapan, Bintan, Semarang, dan Lombok) untuk pasar utama aktivitas MICE di tanah air sesuai acuan Undang-Undang No.10/2009 tentang Kepariwisataan; Dimana pada pasal 14 (1) Usaha pariwisata meliputi, antara lain: (h) penyelenggaraan pertemuan, perjalanan insentif, konferensi, dan pameran.

Pameran sebagai salah satu bagian dari wisata MICE yang telah meningkat pesat secara lokal, nasional, dan internasional. Asosiasi Perusahaan Pameran Indonesia (Asperapi) mendata penyelenggaraan pameran tahun 2017 dengan jumlah 367 pameran meningkat $14 \%$ dari realisasi tahun 2016 dengan jumlah 321 pameran. Pergerakan industri pameran masih berada dikota-kota besar di pulau Jawa, terutama kota Jakarta.

Dalam menunjang hal tersebut salah satu museum yang baru saja diresmikan di D.K.I Jakarta adalah Museum MACAN (Modern and Contemporary Art in Nusantara). Museum ini terletak di Wisma AKR, Jl. Panjang No.5, RT.11/RW.10, Kebon Jeruk, Jakarta Barat. Museum MACAN adalah museum pertama di Indonesia yang memiliki koleksi seni modern dan kontemporer Indonesia serta internasional. Resmi dibuka pada tanggal 3 November 2017, museum ini masih tergolong sebagai destinasi wisata yang baru dikalangan masyarakat Indonesia dan masih berkembang.

Tingkat kunjungan menjadi hal penting yang mempengaruhi pengembangan museum MACAN. Hal ini dikarenakan sumber pendapatan dalam program-program dan pelaksanaan pengembangan museum MACAN, salah satunya berasal dari pejualan tiket kepada para pengunjung yang datang. Museum MACAN Menurut pernyataan ahli, Sharpley dan Wahab dalam Pitana (2005:58) menyatakan motivasi merupakan pemacu dari proses perjalanan wisata, sehingga dapat mempengaruhi tingkat kunjungan berwisata.

\section{TINJAUAN PUSTAKA Motivasi}

Menurut Sharpley (1994) dan Wahab (1975) dalam Pitana (2005:58), Motivasi merupakan hal yang sangat mendasar dalam studi tentang wisatawan dan pariwisata, karena motivasi merupakan trigger dari proses perjalanan wisata, walaupun motivasi ini acapkali tidak disadari secara penuh oleh wisatawan itu sendiri. Lebih lanjut lagi, McIntosh dan Murphy dalam Olivia (2017:18) yang menyatakan motivasi seseorang melakukan wisata adalah sebagai berikut:

a. Physical Motivations (Motivasi Fisik): Hal ini banyak hubungannya 
dengan hasrat untuk mengembalikan kondisi fisik, beristirahat, santai, berolahraga, atau pemeliharaan kesehatan agar kegairahan bekerja timbul kembali.

b.Cultural Motivations (Motivasi Budaya): Motivasi ini erat hubungannya dengan keinginan pribadi seseorang untuk melakukan perjalanan wisata agar dapat melihat dan mengetahui negara lain, penduduknya, tata cara hidupnya serta adat istiadatnya yang berbeda dengan negara lainnya.

c. Interpersonal Motivations (Motivasi Interpersonal): Motivasi yang didorong oleh keinginan seseorang untuk mengunjungi sanak keluarga atau teman atau juga orang-orang baru dan bisa juga untuk menghindari diri dari lingkungan kerja, ingin mencari teman-teman baru dan lain lain. Secara singkat motivasi ini erat hubungannya dengan keinginan untuk melarikan diri dari kesibukan rutin seharihari.

d. Fantasy Motivation atau Status and Prestige Motivations (Motivasi Fantasi atau Status dan Prestige): Motivasi yang didasari oleh fantasi mengenai daerah lain atau maksud seseorang untuk memperlihatkan kedudukan atau statusnya dalam masyarakat demi gengsi maupun pengakuan.

\section{Wisata Museum}

Secara etimologis kata "pariwisata" berasal dari dua suku kata. Suku kata tersebut adalah "pari" dan "wisata". Pari berarti banyak, berkali kali, lengkap, berputar - putar, dan Wisata berarti perjalanan, berpergian yang dalam hal ini sinonim dengan kata "travel" dalam bahasa inggris. Maka "pariwisata" diartikan sebagai sebuah perjalanan yang dilakukan berulangkali dari suatu tempat ke tempat lain. (Yoeti, $1996: 112$ )

Chen, Chen, Ho, dan Lee (2009) memaparkan urutan evolusi pariwisata yang didasarkan pada bentuk produk pariwisata, yang dimulai dari traditional tourism, leisure tourism, thematic tourism, dan terakhir in-depth tourism. In-depth tourism akan lebih banyak menekankan pada berbagai dimensi manfaat seperti pendidikan/pembelajaran, kualitas dan pengalaman. Melihat karakteristik tersebut maka wisata museum dapat dikategorikan sebagai produk in-depth tourism.

\section{Museum}

Menurut International Council of Museum (ICOM), yang diadopsi oleh Sidang Umum ke-22 di Wina, Austria pada 24 Agustus 2007:

"A museum is a non-profit, permanent institution in the service of society and its development, open to the public, which acquires, conserves, researches communicates and exhibits the tangible and intangible heritage of humanity and its environment for the purposes of education, study and enjoyment".

Berdasarkan paragraf diatas, dapat diartikan museum adalah lembaga nirlaba dan permanen dalam pelayanan masyarakat dan pengembangannya, terbuka untuk umum, yang mengakuisisi, melestarikan, meneliti, mengkomunikasikan dan menunjukkan warisan kemanusiaan dan lingkungan yang berwujud maupun tidak berwujud untuk tujuan pendidikan, belajar dan kenikmatan. Hal ini sejalan dengan apa yang disampaikan Camarero et al seperti dikutip Komarac (2014) yang memposisikan Museum sebagai organisasi yang dikaruniai karakteristik unik yang dipersepsikan non-profit dimana tujuantujuan sosial (pendidikan, konservasi, penjagaan, dan lain-lain) menguasai.

Komarac (2014) juga berpendapat bahwa Museum merupakan bagian dari sebuah lingkungan hiburan dan budaya yang lebih luas, yang dikuasai oleh pengunjung yang memiliki tuntutan tinggi dengan mencari pengalaman mendalam (edutainment) dan pengaturan yang hemat waktu. Dari penjelasan di atas maka bisa disimpulkan bahwa secara umum pengunjung Museum juga memiliki karakteristik yang cenderung berbeda dengan wisatawan pada umumnya. 


\section{METODE PENELITIAN}

\section{Metode dan Unit Analisis Penelitian}

Metode yang digunakan adalah metode deskriptif kuantitatif. Metode Penelitian Deskriptif merupakan penelitian berupa pengumpulan data untuk mengetes pertanyaan penelitian atau hipotesis yang berkaitan dengan keadaan dan kejadian sekarang sesuai dengan apa adanya dengan tujuan menggambarkan secara sistematis fakta dan karakteristik objek atau subjek yang diteliti secara tepat (West, 1982 dalam Darmawan, 2013:38).

Adapun, penelitian kuantitatif adalah suatu proses menemukan pengetahuan yang menggunakan data berupa angka sebagai alat menemukan keterangan mengenai apa yang ingin kita ketahui (Margono, 1997 dalam Darmawan, 2013:37).

Definisi unit analisis menurut Kusmayadi dan Sugiarto (2000:73) adalah unit yang diamati dan dijelaskan, serta merupakan objek penelitian yang dapat berupa individu perorangan, kelompok organisasi, masyarakat, hasil karya manusia, instansi dan sebagainya. Dalam penelitian ini, unit analisisnya adalah pengujung yang berkunjung ke museum MACAN.

\section{Variabel dan Pengukurannya}

Variabel yang digunakan dalam penelitian ini adalah 1 (satu) variabel yaitu variabel motivasi pengujung berdasarkan teori motivasi McIntosh (1980) dan Murphy (1985) dalam Olivia (2017:18).

Adapun skala yang digunakan dalam penelitian ini adalah:

1. Skala nominal adalah skala yang hanya mengelompokan suatu fenomena kedalam 2 atau lebih kategori. Kategori tersebut tidak menunjukan tingkatan dan biasanya dinyatakan dalam bentuk angka atau abjad (Kusmayadi dan Sugiarto, 2000:166).

2. Skala Ordinal adalah pengelompokan kategori disusun berdasarkan tingkatan (ranking). Tingkatan ini dapat disusun dari tertinggi sampai terendah atau sebaliknya (Kusmayadi dan Sugiarto, 2000:166).

3. Skala Interval memiliki ciri-ciri yang sama dengan skala ordinal. Bedanya, pada skala interval tingkat perbedaan antara satu kategori dengan kategori lainnya dapat diketahui (Kountur, 2007:51). Pengukuran variabel yang digunakan dalam penelitian ini adalah menggunakan skala Likert. Skala Likert merupakan alat untuk mengukur sikap dari keadaan yang sangat positif ke jenjang yang sangat negative, untuk menunjukkan sejauh mana tingkat persetujuan atau ketidaksetujuan terhadap pernyataan yang diajukan oleh peneliti (Kusmayadi dan Sugiarto, 2000:94).

\section{Populasi dan Sampel}

1. Populasi

Populasi adalah keseluruhan elemen sejenis, akan tetapi dapat dibedakan satu sama lain karena adanya nilai karakteristik yang berlainan (Kusmayadi, 2004:20). Populasi penelitian ini yaitu seluruh pengunjung museum MACAN periode pertama (November 2017 - Maret 2018) sejumlah 135.000 pengunjung. (Sumber data: Wawancara dengan tim Edukasi Museum MACAN)

\section{Sampel}

Sampel adalah bagian dari populasi yang dianggap mewakili karakteristik suatu populasi (Kusmayadi, 2004:20). Teknik yang digunakan untuk pengumpulan data dinamakan teknik sampling. Untuk menentukan jumlah sampel ditetapkan dengan menggunakan formula yang dikembangkan oleh Slovin (1990) dalam Kusmayadi dan Sugiarto (2000:74) dan didapatkan sebanyak 100 orang. Jumlah sampel yang akan diambil dari wisatawan yang mengunjungi Museum MACAN sebanyak 100 orang atau responden.

Penelitian ini menggunakan Probability Sampling dengan menggunakan teknik Sampel Acak Sederhana (Simple Random Sampling). Probability Sampling adalah teknik pengambilan sampel yang elemen 
populasinya mempunyai peluang yang sama untuk dipilih sebagai sampel (Kusmayadi, 2004:66).

Data yang dikumpulkan akan diklarifikasikan dalam bentuk tabulasi kemudian hasil data tersebut akan penulis jelaskan dan interprestasikan ke dalam bentuk deskriptif.

\section{Prosedur Pengumpulan Data}

Data dalam penelitian ini dapat diperoleh melalui 2 cara, yaitu:

\section{Data Primer}

adalah informasi yang diperoleh dari sumber-sumber primer, yakni yang asli, informasi dari tangan pertama, atau responden (Wardiyanta, 2006:28). Adapun pengumpulan data yang digunakan dalam penelitian data primer adalah dengan menggunakan kuisioner, observasi dan wawancara.

\section{Data Sekunder}

adalah informasi yang diperoleh tidak secara langsung dari responden, tetapi dari pihak ketiga. Dalam hal ini yang dimaksud adalah data diperoleh melalui literature berupa buku referensi, laporan tahunan, artikel - artikel dari situs web, koran maupun majalah online.

\section{Metode Analisis Data}

Metode yang digunakan adalah metode analisis data deskriptif. Data yang telah ada, baik data primer maupun sekunder dikumpulkan dan kemudian dilakukan kegiatan menganalisis data data tersebut. Kegiatan menganalisis data terdiri dari 3 tahap, yaitu:

1. Tahap Persiapan, dilakukan pengecekan data dan mengumpulkan semua data yang telah diperoleh. Tahap ini dilakukan dengan melihat catatan dokumentasi tempat dan melihat hasil kuesioner.

2. Tahap Pengolahan data, dilakukan analisis dari kuesioner yang telah disebarkan dengan menghitung frekuensi dari masing - masing jawaban dari kuesioner sebanyak 100 responden, kemudian menghitung persentase jawaban responden dilakukan dengan menggunakan alat bantu software.
3. Tahap Penarikan Sampling dimana pada tahap ini akan diperoleh kesimpulan apa yang menjadi motivasi pengunjung untuk mengunjungi Museum MACAN sebagai daerah tujuan wisata.

\section{HASIL DAN PEMBAHASAN}

Dari hasil demografi responden, mayoritas pengunjung yang datang ke Museum Macan berjenis kelamin perempuan. Hal ini mungkin terjadi karena perempuan yang mengedepankan perasaan akan secara alami lebih tertarik kepada keindahan yang ditemukan dalam seni dibandingkan dengan lelaki yang lebih memakai logika. Pengunjung yang datang berdomisili paling banyak di DKI Jakarta. Hal ini menunjukkan bahwa di luar ibukota DKI Jakarta Museum MACAN belum sepopuler objek wisata budaya lain yang lebih dulu ada semisal kota tua. Selain itu, seperti yang dikemukakan pada bagian teori di atas, wisata museum merupakan sebuah wisata budaya dimana tujuannya tidak sematamata leisure akan tetapi lebih menitikberatkan pada sisi edutainment, sehingga walaupun sebenarnya bisa dinikmati semua kalangan usia dan latar belakang, akan tetapi hanya orang-orang tertentu yang tertarik untuk berkunjung. Usia mayoritas pengunjung adalah 21-30 tahun, dengan latar belakang pendidikan terakhir adalah $\mathrm{SMA} / \mathrm{K}$, dan mayoritas pekerjaan sebagai pelajar/mahasiswa. Temuan ini menunjukkan bahwa kebanyakan pengunjung yang datang mungkin memiliki tujuan lain yang berkaitan dengan keperluan pembelajaran mereka, misalkan keperluan tugas dan penelitian, dan bukan sekedar berkunjung untuk menikmati karya seni. Kemungkinan lain adalah karena yang dipajang adalah seni kontemporer- dan bukan seni tradisional- maka peminatnya lebih banyak datang dari usia generasi milenial.

Dari hasil pembobotan diketahaui bahwa motivasi budaya merupakan motivasi yang paling dominan dibandingkan dengan motivasi lainnya 
dengan nilai rata-rata per topik sebesar 4,16. Hal ini menunjukan bahwa pengunjung yang datang sangat termotivasi untuk menikmati pameran seni yang menarik dengan nilai 4,30, dan juga konsep atraksi pertunjukan seni yang menarik dengan nilai 4,13 , serta memperluas wawasan mengenai seni budaya internasional dengan nilai 4,18 dan wawasan mengenai seni kontemporer dengan nilai 4,13. Hal ini berkaitan dengan tujuan/fungsi awal didirikannya museum sebagai sarana edukasi publik melalui seni skala internasional di Indonesia. Motivasi fisik menempati posisi kedua nilai rata-rata per topik dengan perolehan nilai sebesar 3,96. Pengunjung yang datang ke museum MACAN merasa konsep pameran yang unik dan spesial sehingga mampu mendapatkan pengalaman yang baru dengan nilai perolehan 4,27. Tingginya jumlah pengunjung pada hari libur dan akhir pekan, menyatakan museum MACAN menjadi salah satu tujuan wisata untuk berekreasi dan berlibur dengan nilai 4,08 dan untuk mengisi waktu luang dengan nilai 4,00. Suasana museum yang nyaman juga mampu membuat pengunjung termotivasi untuk melepaskan diri dari rutinitasnya dengan nilai perolehan 3,75 serta bersantai (relaksasi) dengan nilai perolehan.

$$
\text { Motivasi interpersonal dan }
$$

Motivasi status \& prestige dalam berkunjung ke museum MACAN memiliki nilai rata-rata yang sama yaitu 3,60, dimana nilai rata-rata terendah dari motivasi-motivasi lainnya. Pengunjung museum MACAN pada umumnya berpergian tidak sendiri, namun didampingi oleh teman-temannya dengan nilai peroleh 4,18 atau didampingi oleh keluarga/saudaranya dengan nilai perolehan 3,42. Tidak sedikit juga pengunjung museum MACAN datang untuk menjalin pertemanan/relasi baru dengan nilai peroleh 3,21. Hal ini didukung karena museum MACAN memiliki fasilitas khusus bagi para pemegang status keanggotaan, yaitu akses prioritas pada program-program yang ada dan menyaksikan persiapan dibelakang layar program tersebut, dan undangan khusus ke acara-acara eksklusif yang ada, sehingga pengunjung dapat menjalin pertemanan/relasi baru.

Dalam motivasi status \& prestige, pengunjung yang datang paling banyak termotivasi untuk berfoto-foto dengan nilai perolehan 4,13, karena museum MACAN memiliki area-area yang dikhususkan berfoto salah satunya yang favorit adalah infinity mirror room. Responden bangga pernah bekunjung ke museum MACAN dengan nilai sebesar 3,97. Dilain sisi, respondenpun berkunjung kemuseum MACAN untuk mengikuti tren yang sedang terjadi dengan nilai 3,49, dikarenakan museum MACAN merupakan museum seni kontemporer internasional pertama di Indonesia. Alasan mengunjungi museum MACAN untuk keperluan tugas memiliki nilai rata-rata terendah yaitu 2,81 .

Dari nilai keempat motivasi yang terkumpul, hasil perolehan nilai rata-rata keempat motivasi yakni motivasi fisik, motivasi budaya, motivasi sosial dan motivasi fantasi adalah sebesar 3,84 dengan keterangan dibawah ini:

Tabel 1. Skala Interval

\begin{tabular}{|c|c|c|}
\hline \multirow{5}{*}{$x$} & $\theta, \theta \theta=1, \theta \theta$ & ingat Tidak Termotivasi \\
\hline & $1,10-2,00$ & Tidak Termotivasi \\
\hline & $2,10-3,00$ & Kurang Termotivasi \\
\hline & $3,10-4,00$ & Termotivasi \\
\hline & $4,10-5,00$ & Sangat Termotivasi \\
\hline
\end{tabular}

Sumber : Ivona (2016) Analisis Motivasi Pengunjung ke Pasar Lama Sebagai Destinasi Wisata Kuliner di Kota Tangerang

Nilai total rata-rata sebesar 3,84 menunjukan bahwa pengunjung termotivasi untuk mengunjungi museum MACAN didasari oleh beberapa indikator yang telah dinyatakan dalam pembahasan diatas.

\section{KESIMPULAN}

Setelah melakukan penelitian di museum MACAN dengan mencari informasi, menyebarkan kuesioner, mengolah data, mendeskripsikan, dan 
menggambarkan mengenai motivasi yang melatarbelakangi pengunjung datang ke museum MACAN. Maka berdasarkan hasil pembahasan dari ke empat aspek motivasi yaitu Motivasi Fisik, Motivasi Budaya, Motivasi Sosial/Interpersonal, Motivasi Status dan Gengsi, dapat ditarik kesimpulan bahwa:

1. Dari hasil demografi responden, mayoritas pengunjung yang datang adalah perempuan, berdomisili paling banyak di Jakarta, usia mayoritas pengunjung adalah 21-30 tahun, dengan latar belakang pendidikan terakhir adalah $\mathrm{SMA} / \mathrm{K}$, dan mayoritas pekerjaan sebagai pelajar/mahasiswa.

2. Motivasi budaya memiliki nilai rata-rata tertinggi sebesar 4,19 menunjukan bahwa motivasi budaya merupakan motivasi yang paling dominan mendorong pengunjung datang $\mathrm{ke}$ museum MACAN.

3. Motivasi fisik memiliki total nilai rata-rata tertinggi kedua sebesar 3,96 menunjukan bahwa motivasi fisik merupakan motivasi kedua yang melatarbelakangi kedatangan pengunjung ke museum.

4. Diposisi terakhir, motivasi interpersonal dan motivasi status \& prestige dengan total nilai rata-rata yang sama yaitu 3,60. Motivasi ini menjadi motivasi yang paling rendah dalam mempengaruhi kedatangan pengunjung.

5. Hasil penelitian berdasarkan tabel kuesioner memperoleh nilai rata-rata total dari empat motivasi yang dianalisis adalah sebesar 3,84. Dapat disimpulkan bahwa responden setuju dan termotivasi untuk mengunjungi museum MACAN.

Dari kesimpulan diatas, untuk dapat meningkatkan motivasi pengunjung diajukan saran-saran kepada pengelola museum MACAN sebagai berikut:

1. Memperluas area serta memperbanyak atraksi dan pameran dimuseum MACAN, sehingga dapat meningkatkan daya tampung untuk pengunjung dan dapat mengantisipasi antrian yang begitu panjang dan berlapislapis.
2. Menyesuaikan jumlah tiket pengunjung yang dijual untuk setiap sesi kunjungan, agar saat pengunjung berwisata dapat menikmati atraksi lebih leluasa, tidak terlalu padat dan tidak tergesa-gesa.

\section{DAFTAR PUSTAKA}

Chandra, Ardan Adhi \& Damarjati, Danu. (2017). Tiga Tahun Jokowi-JK, Pariwisata Sumbang Devisa Terbesar Kedua. Detik.com. Sumber: https://finance.detik.com/beritaekonomi-bisnis/d-3687715/tiga-tahunjokowi-jk-pariwisata-sumbang-devisaterbesar-kedua (diakses 23 Mei 2018)

Chen, Y.G., Chen, Z-H., Ho, J.C., dan Lee, C-S. (2009). In-depth Tourism's Influences on Service Innovation. International Journal of Culture, Tourism, and Hospitality Research, Vol. 3 No. 4, pp. 326-336.

Darmawan, Deni. (2013). Metode Penelitian Kuantitatif. Bandung: PT Remaja Rodakarya Offset.

International Council of Museum (ICOM). (2007). Museum Definition. http://icom.museum/thevision/museum-definition/ (Diakses 27 Mei 2018)

Junaedi. (2016). Strategi Pengembangan Bisnis MICE untuk Mewujudkan Kota Surakarta sebagai Kota MICE. Jurnal Hotelier Politeknik Indonusa Surakarta, 1(3),45-54.

Kesrul, M. (2004). Meeting Incentive Trip, Conference and Exhibition. Jakarta: Graha Ilmu.

Komarac, T. (2014). A New World for Museum Marketing? Facing the Old Dilemmas while Challenging New Market Opportunities. Trziste, Vol. 26 No. 2, pp. 199-214.

Kusmayadi. (2004). Statistika Pariwisata Deskriptif. Jakarta: Gramedia

Kusmayadi dan Endar Sugiarto. (2000). Metodologi Penelitian dalam bidang Kepariwisataan. Jakarta: PT. Gramedia Pustaka Utama.

Museum: Pengertian, Sejarah, Fungsi, Jenis.

(2017). 
https://www.ilmudasar.com/2017/12/P engertian-Fungsi-Macam-Macam Museum-adalah.html (Diakses $28 \mathrm{Mei}$ 2018)

ONE. (2017). Inilah 16 Destinasi MICE di Indonesia.

Sumber: https://sportourism.id/news/inilah-16destinasi-mice-indonesia (diakses 23 Mei 2018)

Olivia, Rayna Stephanie. (2017). Analisis Motivasi Keikutsertaan Peserta $m$ Seminar The 3Pariwisata Trisakti. $3^{\text {rd }}$ MICE Discovery [skripsi]. Jakarta (ID): STP Trisakti

Pendit, Nyoman.S. (2002). Ilmu Pariwisata Sebuah Pengantar Perdana. Jakarta: Pradya Paramita

Pitana, I. Gede dan Gayatri, Putu G. (2005). Sosiologi Pariwisata Yogyakarta: Andi.

Simanjuntak, Bungaran Antonius, et al. (2015). Sejarah Pariwisata: Menuju Perkembangan Pariwisata Indonesia. Jakarta: Yayasan Pustaka Obor Indonesia.

Sugiyono. (2014). Metode Penelitian Kuantitatif, Kualitatif, dan $R \& D$. Bandung:ALFABETA.

Undang-Undang Republik Indonesia Nomor 10 Tahun 2009 Tentang Kepariwisataan

Wardiyanta. (2006). Metode Penelitian Pariwisata. Yogyakarta: Andi.

World Tourism Organization. -. Glossary

Terms. Sumber: http://statistics.unwto.org/sites/all/files /docpdf/glossaryterms.pdf (Diakses 29 Mei 2018)

Yoeti, Oka A. (1996). Pengantar Ilmu Pariwisata. Bandung: ANGKASA.

Yoeti, Oka. A. (2006). Pariwisata Budaya: Masalah dan Solusinya. Jakarta : Pradnya Paramita. 